\title{
Development of Educational Games for Fundamentals of Marketing Subject
}

Roszi Naszariah Nasni Naseri, Azahar Harun, Raja Nazim Raja Abdullah, Mohd Hanif Mohd Omar

To Link this Article: http://dx.doi.org/10.6007/IJARBSS/v12-i2/12883

DOI:10.6007/IJARBSS/v12-i2/12883

Received: 17 December 2021, Revised: 21 January 2022, Accepted: 06 February 2022

Published Online: 25 February 2022

In-Text Citation: (Naseri et al., 2022)

To Cite this Article: Naseri, R. N. N., Harun, A., Abdullah, R. N. R., \& Omar, M. H. M. (2022). Development of Educational Games for Fundamentals of Marketing Subject. International Journal of Academic Research in Business and Social Sciences, 12(2), 354-360.

Copyright: (c) 2022 The Author(s)

Published by Human Resource Management Academic Research Society (www.hrmars.com)

This article is published under the Creative Commons Attribution (CC BY 4.0) license. Anyone may reproduce, distribute, translate and create derivative works of this article (for both commercial and non0-commercial purposes), subject to full attribution to the original publication and authors. The full terms of this license may be seen

at: http://creativecommons.org/licences/by/4.0/legalcode

Vol. 12, No. 2, 2022, Pg. $354-360$

Full Terms \& Conditions of access and use can be found at http://hrmars.com/index.php/pages/detail/publication-ethics 


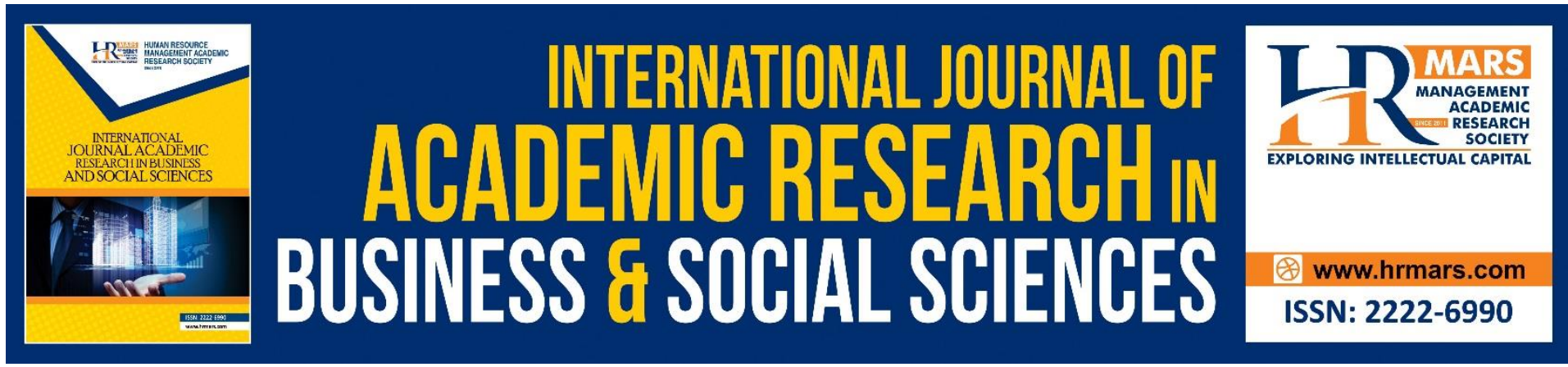

\title{
Development of Educational Games for Fundamentals of Marketing Subject
}

\author{
Roszi Naszariah Nasni Naseri \\ Faculty of Business and Management, Universiti Teknologi MARA 78000 Alor Gajah, Melaka, \\ Malaysia \\ Corresponding Author's Email: roszinaseri@uitm.edu.my \\ Azahar Harun \\ College of Creative Arts, Universiti Teknologi MARA 78000 Alor Gajah, Melaka, Malaysia
}

\section{Raja Nazim Raja Abdullah}

Faculty of Management and Economics, Universiti Pendidikan Sultan Idris, Tanjong Malim, Perak, Malaysia

\section{Mohd Hanif Mohd Omar}

College of Creative Arts, Universiti Teknologi MARA 78000 Alor Gajah, Melaka, Malaysia

\begin{abstract}
This paper proposes a games platform known as Marketing Edu Game which is an educational game purposely made for UiTM Diploma students. It is used as a supplementary aid for students. The game incorporates curriculum content from Marketing (MKT243) subject. The game consists of 10 learning paths, representing 10 chapters. Each learning path has a combination of 10 multiple choices and True/False questions. The Marketing Edu Game is created due to students' hardship to study and revise their subject. This trusted conceptual platform assists students to revise their understanding towards Marketing subject using games as fun learning. This platform has the ability to provide convenient and friendly interface.
\end{abstract}

Keywords: Games, Education, Support Tool, Teaching, Learning, Marketing Subject

\section{Introduction}

Of recent, the rapid growing technological advancement provides a great chance to create new application to solve problems faced by students. Among the most popularly developed in helping the students is educational games that are used to enhance learning experience among students. Games that incorporate educational material and curriculum content are referred to as educational games (Michel, 2016). Similar to that definition, Houghton et al (2013) also outlined that educational games is the utilization of games to support the process of teaching and learning. Games can be used as a support tool to complement conventional 
teaching methods to improve the learning experience of the learners. At the same time, the utilization of educational games also promotes skills that are required in every day's life such as following rules, adaptation, problem solving, interaction, critical thinking skills, creativity, teamwork, and good sportsmanship. An interesting study by Zirawaga et al (2017) has found that the learning should not just be a boring process where students have to memorize to be able to learn and grasp concepts through repetition or cramming of information. For instance, digital game-based learning is already accepted as an instructional method that has very encouraging outcome in adult education and learning (Anderson et al., 2009). This is because digital game-based learning combines useful information in educational content with the use of video games (Turner et al., 2018). A study by Granic and Lobel (2013) had proven that game-based learning increases various abilities related to cognition such as perception, reasoning, critical-thinking, spatial navigation, and memory retention . On top of that, Spires (2015) highlighted that game-based learning is not simply the act of developing games for students to play, but it is also known as the act of designing interactive learning activities that can gradually convey concepts and guide students towards achieving the goal. In short, gamebased learning can be considered as a functional teaching method that empower students to explore different parts of games as a form of learning process to help them enhance their set of skills or achieve specific learning outcomes. However, in designing game-based learning at university level, it is important to ensure that digital games are aligned with the course content and course objectives to achieve the effectiveness of game-based learning (Moylan et al., 2015). Previous studies have discussed the impact of game-based learning in the digital era, where several number of contemporary researches have already acknowledged the potential of digital games to capture student's attention in motivating them to explore the edges of their competence, skills and knowledge (Fokides, 2020; Megagianni and Kakana, 2021). Research by Ding et al (2017) also explored the effectiveness of using digital gamesbased learning on traditional college students. However, it is unfortunate to note that although previous studies have proved the benefit gained through game-based learning, the use of it as supplementary aids at university level is still in the early stages of development (Herro and Clark, 2016; Holmes and Gee, 2016; Moylan et al., 2015). Research and observation have also found that students face difficulties in education and learning during recent pandemic COVID-19. Unfortunately, while many students all over the world are forced to switch to online learning during the pandemic, current system of teaching and learning does not fully utilize games through fun and effective learning. A study by Linehan (2011) had outlined that traditional mainstream education does not motivate all students but only a small minority of them. It has been found that students face hard time to study online during pandemic COVID-19. Based on the survey conducted among 100 UiTM students who take Marketing (MKT243) subject, $80 \%$ said that they have problems in concentrating when lecturers conduct the class using traditional method. The students actually prefer for their lecturers to use educational games as supplementary aid in the class. Hence, the main purpose of this study is to develop a platform that helps students to achieve better understanding in Marketing subject through games.

\section{Methodology}

This research carried out several activities, namely Literature Study, Survey, Application Making, Testing Application, and Post-Test. The research method carried out in this study can be seen in Figure 1. 


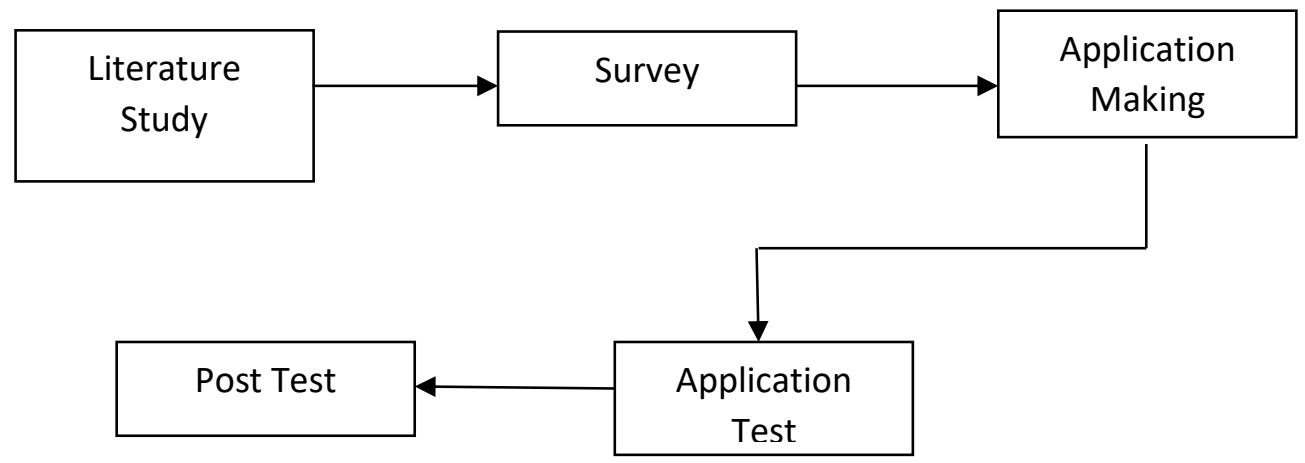

Figure 1. Research Methods Conducted

Adapted from Rachman, Purwanto and Nugroho (2019)

The first step in this study is the literature review. The researchers conducted a literature study during the initial phase. During this stage, researchers looked for information related to research methods that can be used to address questions and problems of students related to fundamentals of the Marketing subject. In the second step, the researchers conducted survey on diploma students from University of Technology MARA Malacca, Malaysia. The target of this study was 100 students who take Fundamentals of Marketing Subject. The researchers used WhatsApp to collect data from respondents. WhatsApp is chosen as a mean of data collection as it has been reported by Bernama (2017) that Malaysia is the largest user in the world at $51 \%$. A URL link to the electronic survey is provided in the invitation message so that interested persons can participate in the survey by clicking on the URL link. The third step is to build an educational game application. To create this application, researchers use visual basic Microsoft. The fourth step is to test the application. This process is conducted after the completion of the application creation phase. After that, the application test was held with 5 students by using the electronic version. Students were required to play the game, and then give their feedback on the understandability, learnability, operability, attractiveness, and usability compliance. The fifth step is to do a post-test. During post-test, students' understanding on the subject was tested after they played the educational game for one week.

\section{Result and Discussion}

In this study, the researchers built an educational game on the chapter of Introduction to Marketing Subject. The game incorporates curriculum content from Fundamental of Marketing (MKT243) subject. The game consists of 10 learning paths, which represent 10 chapters. Each learning path has a combination of 10 multiple choice (Figure 2 ) and True/False questions (Figure 3). 


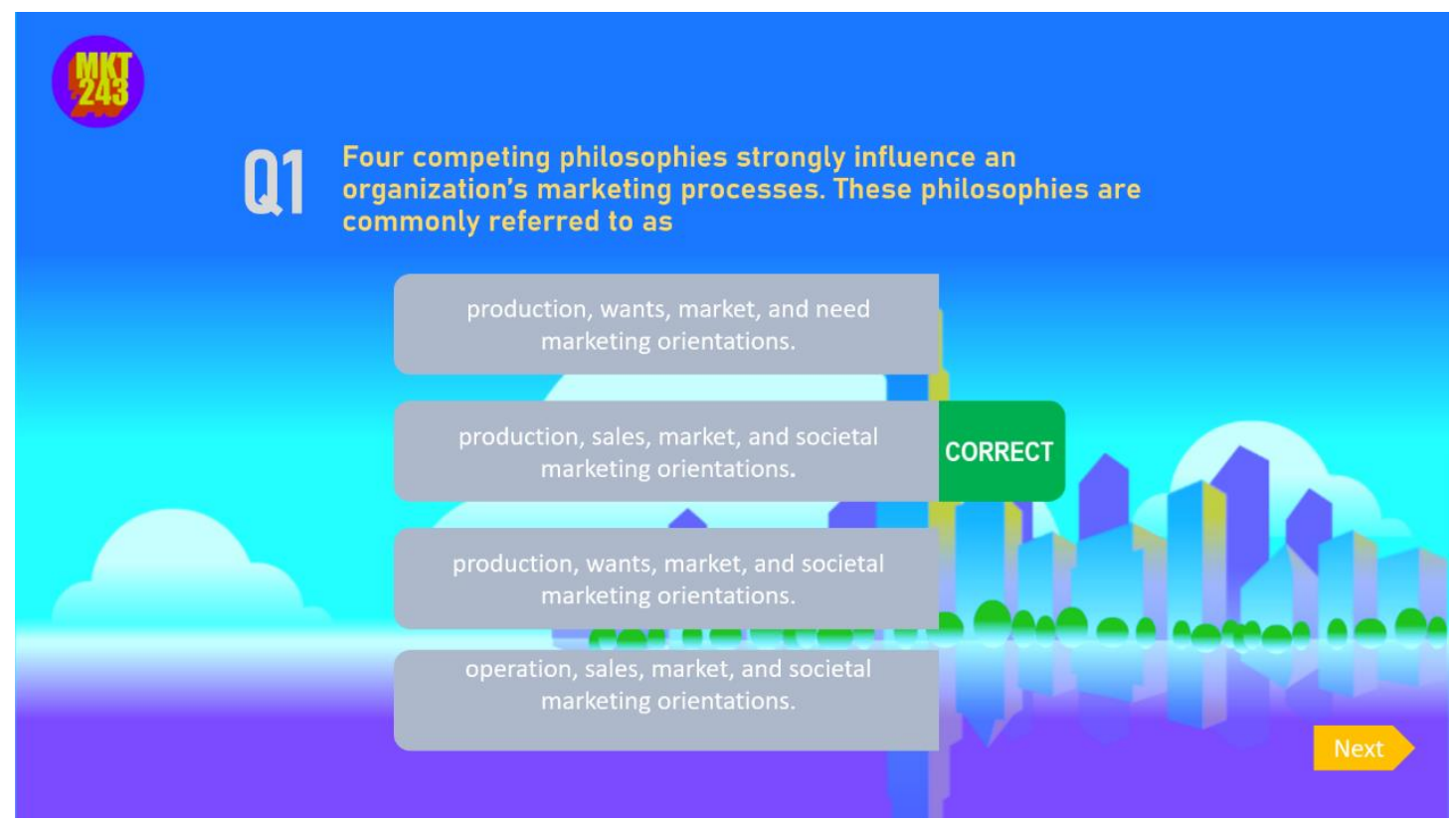

Figure 2. Multiple Choice Questions

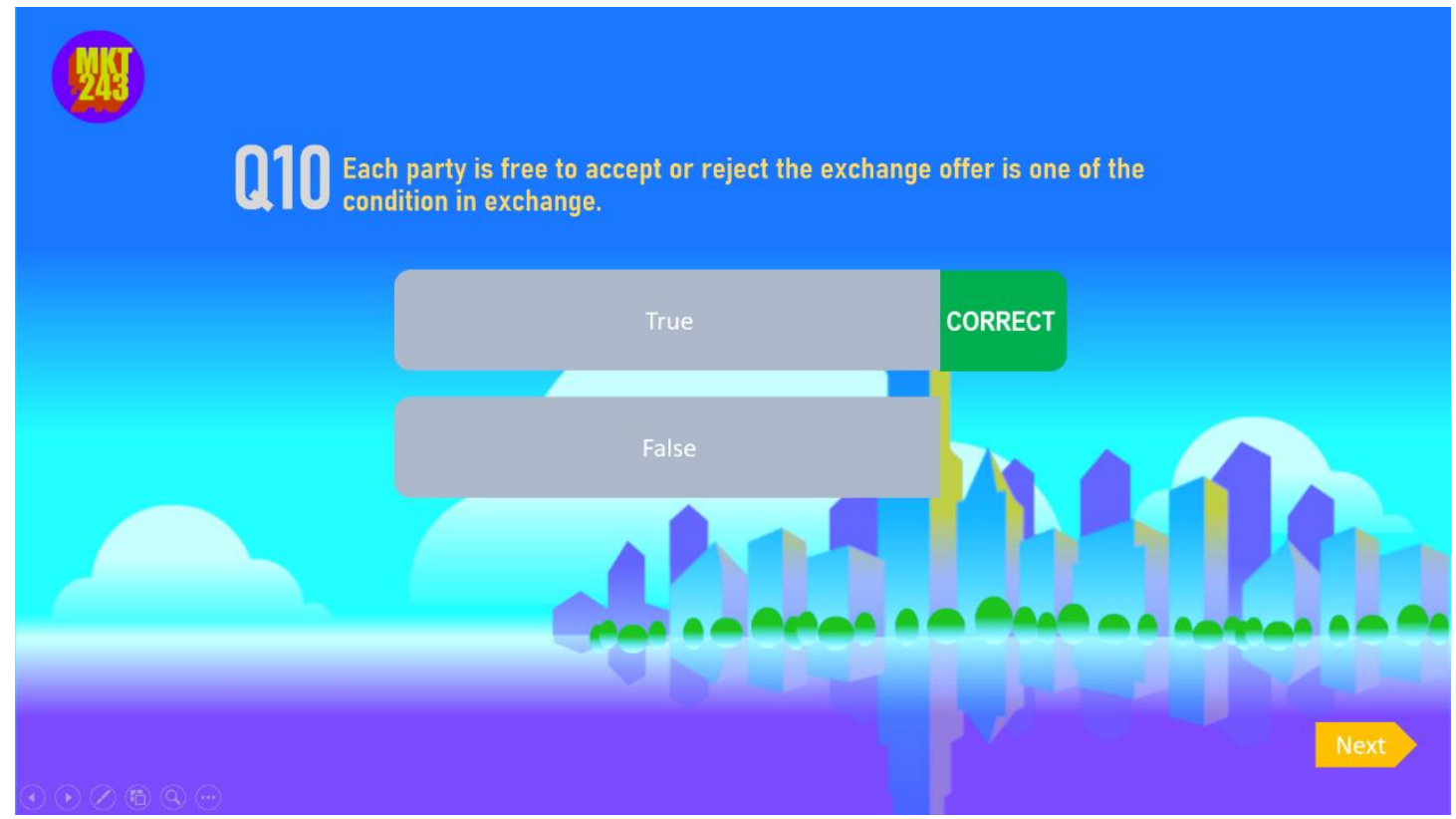

Figure 3. True and False Questions 


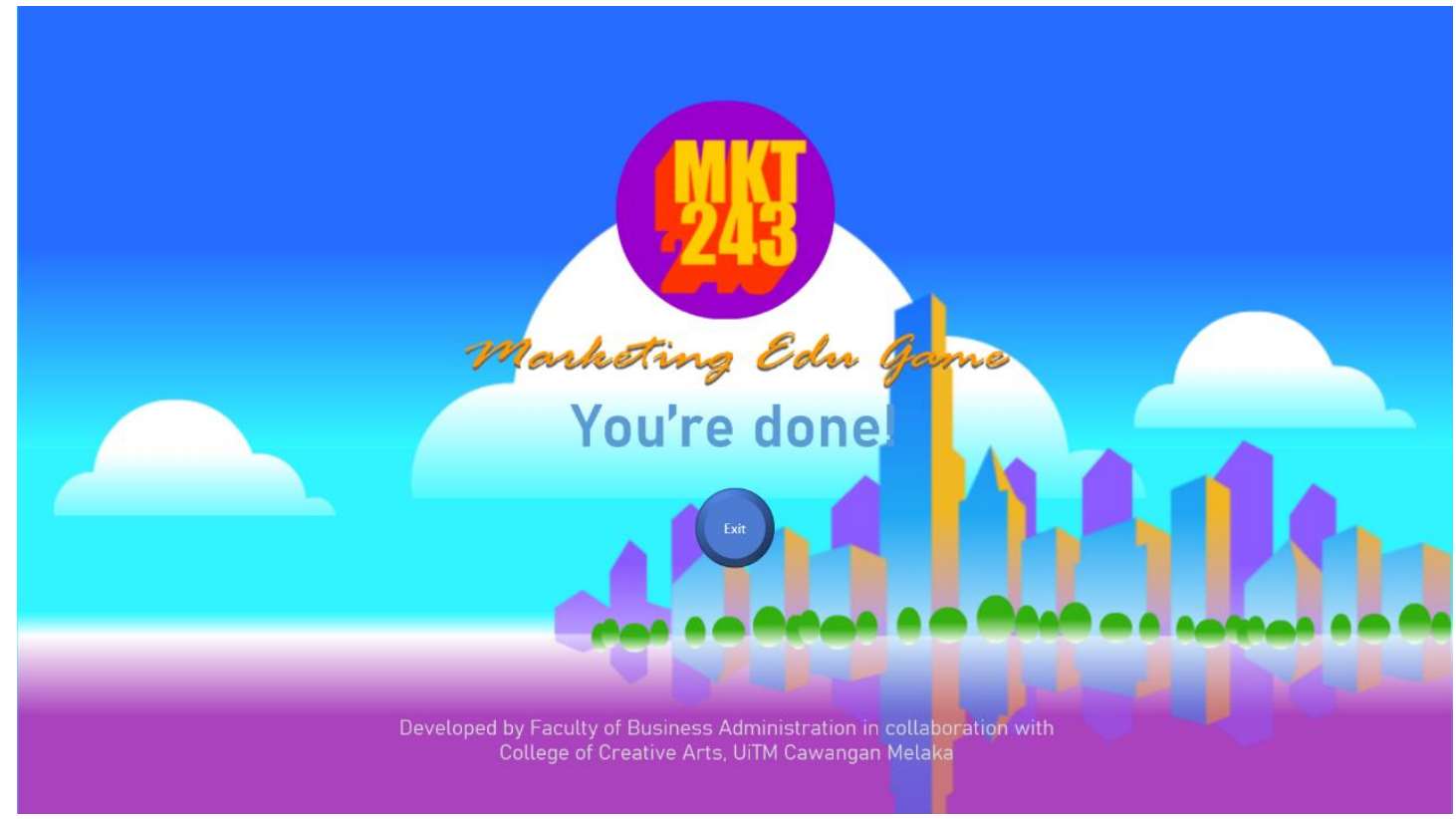

Figure 4. End page

From the results of application test, the game achieved $81 \%$ on students' understandability. On the attributes of learnability, the game received a value percentage of $80 \%$, while on the characteristic of operability, the game achieved $85 \%$. On attractiveness characteristic, the result showed 70\%; and on usability compliance characteristic, the game received a percentage value of $85 \%$. Hence, overall, the game has good and positive feedbacks from the participating students.

\section{Conclusion}

In conclusion, it may be difficult for students to do their revision especially during COVID-19 pandemic. Therefore, the idea of developing a platform such as Marketing Edu Game is timely. The Marketing Edu Game platform provides benefits to students and educators as the game can be used as a platform for teaching and learning. Digital game-based learning method is an educational tool that can help to improve students' well-being and self-esteem. Apart from that, the use of such game can also assist to improve the students' soft skills, develop their critical thinking, decision-making and problem-solving skills, and maintain mental health and psychological balance. Hence it can be concluded that Marketing Edu Game is a functional means of promoting and improving the educational process. The use of the game can instill interest in educational issues, promote learning motivation and participation, while at the same time induce desire and active participation of the students in the curriculum.

\section{Acknowledgment}

The researcher would like to thank Faculty of Business Management and College of Creative Arts, Universiti Teknologi MARA Melaka for the opportunity given to run this study.

\section{References}

Anderson, B. O., Anderson, M. N., \& Taylor, T. A. (2009). New territories in adult education: Game-based learning for adult learners. In Research Conference (p. 1). 
Bernama. (2017). Malaysians' world's largest WhatsApp users. [online] Available at: https://www.malaysiakini.com/news/394912

Fokides, E. (2020). Digital educational games in primary education: Revisiting the results of the research projects of the ETiE initiative. In Epistemological approaches to digital learning in educational contexts (pp. 54-68). Routledge.

Granic I., \& Lobel, A. (2013). Video games play may provide learning, health, social benefits, review finds. [online] Available at: http://www.apa.org/news/press/releases/2013/11/ video-games.aspx

H. A. Spires. (2015). Digital Game-Based Learning. Journal of Adolescent \& Adult Literacy, 59(2), 125-130.

Herro, D., \& Clark, R. (2016). An academic home for play: Games as unifying influences in higher education. On the Horizon, 24(1), 17-28.

Holmes, J., \& Gee, R. (2016). A framework for understanding game-based teaching and learning. On the Horizon, 24(1), 1-16.

Linehan, C., Kirman, B., Lawson, S., \& Chan, G. (2011). Practical, appropriate, empiricallyvalidated guidelines for designing educational games. In Proceedings of the SIGCHI conference on human factors in computing systems (pp. 1979-1988).

Megagianni, P., \& Kakana, D. (2021). The educational value and impact of serious games in cognitive, social and emotional development in middle childhood: perceptions of teachers in Greece. In T. Tsiatsos, S. Demetriadis, A. Mikropoulos, \& V. Dagdilelis (Eds.), Research on E-learning and ICT in education (pp. 129-145). Springer International Publishing.

Michel, H. (2016). Characterizing serious games implementation's strategies: Is higher education the new playground of serious games? Institute of Electrical and Electronics Engineers (IEEE).

Moylan, G., Burgess, A., Figley, C., \& Bernstein, M. (2015). Motivating game-based learning efforts in higher education. International Journal of Distance Education Technologies, 13(2), 54-72. https://doi.org/10.4018/IJDET

Rachman, A., Purwanto, M. Y., \& Nugroho, H. (2019). Development of Educational Games for The Introduction of Fruits and Vitamins. Journal of Educational Science and Technology (EST), 5(1), 76-81.

Reinders, H., \& Wattana, S. (2015). Affect and willingness to communicate in digital gamebased learning. The Journal of EUROCALL, 27(1), 38-57.

Turner, P. E., Johnston, E., Kebritchi, M., Evans, S., \& Heflich, D. A. (2018). Influence of online computer games on the academic achievement of nontraditional undergraduate students. Cogent Education, 5(1), 1437671.

Zirawaga, V. S., Olusanya, A. I., \& Maduku, T. (2017). Gaming in education: Using games as a support tool to teach history. Journal of Education and Practice, 8(15), 55-64. 